\title{
Modelo de gestión por procesos para mejorar el desempeño en el área Agri-Food
}

Gabriel Delgado Seclén Willy CALSINA Miramira ${ }^{2}$

RECIBIDO: 14/12/2018 AcEPTADO: 08/07/2019

\begin{abstract}
RESUMEN
El actual trabajo de investigación propone mejoras en el área Agri-Food, donde se presentan problemas como: quejas de los clientes, quienes manifiestan que los auditores e inspectores no llegan a la hora pactada; falta de procedimientos, los cuales generan desconcierto en los clientes debido a que los inspectores ejecutan diversas formas de trabajo para un mismo servicio; y, por último, carecen de un control de entrada y salida de materiales almacenados, por lo que muchas veces faltan artículos que son requeridos por todo el personal de la organización. Después de haber expuesto los problemas en el área Agri-Food, el presente estudio busca mitigar estos problemas que afectan directamente al departamento, pues el cliente se está llevando una mala impresión del servicio. Asimismo, el trabajo se desarrolló en una organización que brinda servicios de inspección, auditorias, ensayos y certificados. El objetivo de la investigación es determinar el impacto de un modelo de gestión por procesos en el desempeño del área Agri-Food, con la finalidad de reducir la cantidad de quejas, estandarizar las actividades ejecutadas por los inspectores en campo y contar con los materiales requeridos por todos los colaboradores. El diseño de la investigación es cuasiexperimental y de tipo serie de tiempo, se ha aplicado estadística descriptiva e inferencial. Finalmente, los resultados obtenidos son: reducción de quejas, estandarización de trabajos en campo y pedidos atendidos, todo ello se puede visualizar en las pruebas de hipótesis.
\end{abstract}

Palabras-claves: Gestión por procesos; quejas; procedimientos; materiales.

\section{INTRODUCCIÓN}

El presente estudio se desarrolló en una empresa de servicios dedicada a realizar inspecciones, auditorías, ensayos y certificación de alimentos solicitados por entidades públicas y privadas. El presente trabajo se ejecutó en el área Agri-Food, dado que la empresa tiene problemas en sus diferentes subáreas.

De acuerdo al manual de procedimientos de la empresa en estudio, los colaboradores del departamento de certificaciones acuerdan con los clientes la fecha, hora y el lugar en donde se llevará a cabo la inspección, auditoría o muestreo. Según el área de operaciones, es este el lugar donde se genera el primer problema: no se logra elaborar procesos que permitan planificar las operaciones, esto conlleva a tomar decisiones improvisadas que incumplen con los acuerdos de trabajo y ocasionan desorden en general. Posteriormente, el departamento de certificaciones envía un correo al área de operaciones informando el servicio que se acordó con el cliente y la siguiente programación de los trabajos. Luego, el coordinador designa al inspector y le hace entrega de los documentos para que, a su vez, pueda realizar las actividades en su campo. Según el área de certificaciones, los clientes envían correos (quejas) informando que el personal aún no llega a las instalaciones de la planta, almacén o empresa. Estas demoras pueden originar que los usuarios se lleven una mala impresión de la corporación y opten por contratar a otras certificadoras. Así, esto se vería reflejado en las ventas, produciendo un impacto negativo en las utilidades de la organización.

Por otro lado, los departamentos de la empresa de servicios realizan pedidos al área de compras, los cuales muchas veces no se entregan en la fecha establecida. Por ello, el área de compras, para solucionar estos problemas, realiza pedidos de emergencia a los proveedores, en el que existe un recargo del $15 \%$ por estos pedidos y que se refleja directamente en los costos, debido a que no se realiza una buena gestión. También el área de compras menciona que carecen de un control de entrada y

1 Ingeniero industrial por la Universidad Señor de Sipán. Actualmente, es supervisor de Intertek Testing Services Perú S. A., Lima.

E-mail: juan.delgado@intertek.com

2 Ingeniero industrial y magíster en Gestión de Alta Dirección por la Universidad Nacional Mayor de San Marcos.

E-mail: willy.calsina@unmsm.edu.pe 
salida de materiales almacenados, falta de artículos como precintos, bolsas plásticas, botellas plásticas, cintas, material de oficina, etc., que los inspectores, supervisores, auditores y colaboradores utilizan en campo y en las instalaciones de la empresa. Otro déficit identificado, según el área de compras, es el desconocimiento del costo de la organización al emitir una orden de compra, cuando se debe realizar un pedido y la cantidad óptima a pedir; estos factores se deben considerar porque conllevará a una mejor gestión de costos de inventarios.

Asimismo, carecen de procedimientos que sirvan de guía para los inspectores al ejecutar las operaciones en campo, los cuales generan que no se tengan estandarizadas las actividades. Además, aquello podría crear desconcierto en el cliente, debido a que los inspectores ejecutan diversas formas de trabajo, y confusión en las instituciones del Estado - como Sanipes y Digesa-, encargadas de evaluar las competencias técnicas del inspector. Estas entidades podrían sancionar a la empresa con la inhabilitación de las operaciones, así como la realización de auditorías internas con la finalidad de calificar el nivel de competencia técnica de los inspectores. Es importante que la organización tenga los objetivos claros, lograr que sea entendida y compartida por todos los integrantes de la empresa, de lo contrario, los resultados no serán favorables y se verán reflejados en la productividad y rentabilidad de la corporación; y, sobre todo, puede repercutir en la insatisfacción de los clientes, pues no se están alcanzando las metas debido a que no se estructuraron adecuadamente. De mantenerse esta situación, la organización seguirá incurriendo en pérdidas, lo cual podría generar que los clientes cancelen los servicios y opten por trabajar con otras certificadoras, ocasionando grandes pérdidas; bajo este escenario, la empresa terminaría en quiebra.

\section{MARCO TEÓRICO}

Con respecto al término "gestión», Muñoz y Andrade (2017) refieren que este es un conjunto de etapas o pasos que se ejecutan para solucionar un trabajo, definir un proyecto o gestionar una corporación u organización. Gallego (2013) señala que existen tres grupos de procesos: el primero es el nivel estratégico, que comprende actividades vinculadas con la definición de la misión, visión, las metas de la empresa y el diseño de estrategias. En el segundo grupo están los procesos operativos, que son aquellos que se relacionan directamente con las tareas productivas de la organización y están vinculadas con la ejecución del producto o servicio. Por último, el nivel de apoyo se encarga de dar soporte a todos los departamentos de una organización.

Imbaquingo (2013) define la gestión por procesos como la mejora de todas las tareas, actividades y procesos, agregando valor a cada actividad, desde el inicio hasta el final, la cual a su vez impacta en la satisfacción y las expectativas del consumidor. Mientras que Mallar (2010) define la gestión por procesos como un modelo de dirección oportuno para el momento actual, utilizado por diferentes empresas que buscan eficiencia en las operaciones y lograr resultados cada vez mejores. Como se puede apreciar en las definiciones de ambos autores, existen coincidencias en los puntos que abordan la adición de valor a todos los procesos para lograr satisfacer las necesidades y los requerimientos del cliente.

Pérez (2004) sostiene que planificar es hacer adecuadamente las cosas para conseguir los objetivos perseguidos. Idea que sigue la Junta de Castilla y León (2004), la cual señala que la planificación se inicia con la evaluación, el análisis y diseño de las diferentes tareas y actividades con el propósito de desarrollar los diferentes puestos de trabajo (descripción del sistema de recursos humanos, fijación y seguimiento de objetivos de las distintas unidades, etc.). Es relevante la implementación de la planificación de servicios para evitar cualquier tipo de queja y reclamo. Sobre ello, la Organización Internacional de Estandarización define la queja como la expresión de insatisfacción hecha a una organización, con respecto a sus productos y servicios, que se produce al fracasar en el cumplimiento de las necesidades del consumidor.

El estudio de Pérez (2017) mejoró los plazos de entrega, los cuales generaban malestar en los clientes, y los redujo de $67,06 \%$ a $62,38 \%$ en el primer mes mediante la disminución del tiempo; esta acción produjo un impacto positivo en el nivel de cumplimiento. Para la planificación de los recursos, el autor utilizó el diagrama de Gantt; además, el escenario donde se desarrolló la investigación fue en una empresa textil. Si bien es cierto que el estudio y trabajo presentes ocurren en dos sectores diferentes, el objetivo es el mismo: planificar los recursos y utilizarlos eficientemente. Suárez (2017) asoció las actividades de los puestos y las áreas de las organizaciones a través de una secuencia de trabajo que establece la forma y procedimientos que buscan la máxima productividad, generando en paralelo alcanzar los objetivos y la satisfacción del consumidor. El autor hace énfasis en señalar que, para que exista máxima eficiencia, necesariamente se debe planear, gestionar y mejorar las actividades 
para satisfacer a los clientes internos y externos. Valenzuela (2017) realizó su estudio con el propósito de comprobar si existe relación entre la gestión por procesos y el clima social laboral con planificar los recursos, definir las actividades y programar los planes operativos de la institución.

Los resultados obtenidos permitieron concluir que existe una relación positiva moderada entre las variables, incluso el escenario es similar al presentado en este artículo, puesto que es importante conocer las actividades y, sobre todo, ponerlas en práctica con la finalidad de estandarizar los procesos y reducir las desviaciones que se puedan presentar antes, durante y después de brindar algún bien o servicio. Díaz (2015) priorizó la implementación de procedimientos, diagramas de flujos e indicadores de gestión con la finalidad de conocer mejor las actividades y procesos, además de evaluar si se cumplen los objetivos de la organización. El autor señala que se deben conocer los procesos, que se logra mediante los procedimientos y diagramas de flujo. También mencionó que es importante medir los procesos para determinar si se están alcanzando o no los propósitos; si no se consiguen, se deben establecer otros mecanismos para cumplir con los fines y lograr las metas. Ese estudio se enfoca en las pymes de la industria gráfica, a pesar de que el escenario de la investigación es diferente, el objetivo del autor es documentar los procesos e implementar los procedimientos y diagramas que permitan conocer mejor las actividades, y utiliza la norma técnica ecuatoriana para implementar el modelo de gestión por procesos. Así, se utilizaron las normas técnicas de entidades del Estado como Sanipes, Inacal y Digesa, de acuerdo a las actividades que se dedica la empresa de servicios. Además, es relevante cumplir con los procedimientos establecidos por las instituciones del Estado; caso contrario, sería sancionada. De esta manera, el objetivo principal de la implementación de los procedimientos fue estandarizar los trabajos en campo y evitar confusiones en los clientes, debido a que afirmaron que los inspectores ejecutaban de diferentes formas el trabajo, a pesar de ser el mismo servicio.

La investigación de Merino (2015) se interesó en demostrar la existencia de la relación entre la gestión por procesos y las capacidades de gestión administrativas. El resultado fue que existe evidencia significativa para afirmar que hay una relación entre ambas variables. Asimismo, el propósito de la investigación es cumplir con los objetivos de la sede central de EsSalud, por lo que busca solucionar sus problemas con la utilización del modelo de gestión por procesos para cumplir con los objetivos de la entidad mediante la planificación de servicios.

En la misma línea de estudios, Castillo (2013) señala que la falta de procedimientos y procesos para el registro de gastos financieros, trámites de compras y presupuestos genera demoras en las actividades administrativas. El interés del autor es describir los procesos e implementar procedimientos con el propósito de estandarizar las actividades y reducir los tiempos de demoras que existen al realizar los trámites administrativos. Este trabajo implementó procedimientos de inspección y muestreo de productos basados en las normas técnicas peruanas, con el objetivo de estandarizar los trabajos ejecutados en campo por los inspectores y cumplir lo dispuesto por las instituciones del Estado.

En ese sentido, el estudio de Herrera (2013), descrito anteriormente, señala que la finalidad fue identificar los problemas, analizar los procesos y actuar de manera oportuna. Por ello, se diseñaron indicadores de gestión para medir el cumplimiento de los objetivos y documentar la información. El autor enfatizó que el éxito de la organización se logra cuando se satisface al cliente externo e interno y se aprovecha eficientemente los recursos de la empresa. Además, señaló que la gestión por procesos permitió tener ventajas frente a otras empresas y realizar un mejoramiento continuo de sus procesos. Este artículo priorizó no solo la implementación del procedimiento, sino también la planificación de servicios, principales problemas que tenía el área Agri-Food.

\section{METODOLOGÍA}

La presente investigación es de tipo experimental, pues se va a manipular en forma intencional una o varias variables independientes (Hernández et al., 2010).

\section{Diseño}

El diseño es cuasiexperimental y de tipo serie de tiempo (Sánchez y Reyes, 2002).

\section{Población}

Todas las solicitudes de inspección.

\section{Muestra}

385 solicitudes de inspección.

\section{Hipótesis}

La planificación de servicios reduce la cantidad de quejas. 


\section{Variable dependiente}

Cantidad de quejas.

\section{Variable independiente}

Planificación de servicios.

\section{Escala de medición}

Nominal.

\section{Estadístico descriptivo}

La operación matemática o estadística descriptiva que se utilizó fue el conteo.

\section{Análisis inferencial}

Prueba de bondad de ajuste chi-cuadrada.

\section{Técnicas}

Se utilizaron la revisión de gabinete y la observación, técnicas fundamentales que ayudaron al investigador a obtener los datos.

\section{Instrumentos}

El instrumento que se usó fue el archivo de Excel y el checklist, el cual fue entregado por el área de certificaciones y operaciones.

\section{RESULTADOS}

A continuación, se expone la hipótesis:

$\mathrm{Hi}$ : la planificación de servicios reduce la cantidad de quejas.

Donde se tiene:

X: implementación de la planificación de servicios.

Y: cantidad de quejas.

- Unidad de análisis: solicitud de inspección.

- Población: todas las solicitudes de inspección del área Agri-Food (infinito).

- Muestra: pretest de 385 solicitudes de inspección y postest de 385 solicitudes de inspección.

Antes de exponer los resultados, se plantearon las siguientes hipótesis:

$$
\begin{aligned}
& \mathrm{HO}: \mathrm{u} 1=\mathrm{u} 2 \\
& \mathrm{Hi}: \mathrm{u} 1 \neq \mathrm{u} 2
\end{aligned}
$$

$$
\alpha=0,05
$$

En donde:

u1: cantidad de quejas de la situación pretest.

u2: cantidad de quejas de la situación postest.

a: nivel alfa o también llamado nivel de error.

En la siguiente tabla se presenta la prueba de bondad de ajustes chi-cuadrada:

Tabla 1. Quejas.

\begin{tabular}{|c|c|c|c|}
\cline { 2 - 4 } \multicolumn{1}{c|}{} & $\mathbf{N} .^{\circ}$ observado & $\mathbf{N}^{\circ}$ esperado & Residuo \\
\hline 0 & 345 & 219,5 & 125,6 \\
\hline 1 & 40 & 165,5 & $-125,6$ \\
\hline Total & 385 & & \\
\hline
\end{tabular}

Fuente: elaboración propia.

En la siguiente tabla, se muestran los resultados de la prueba anterior:

Tabla 2. Resultados de la prueba de bondad de ajustes chi-cuadrada.

\begin{tabular}{|c|c|}
\hline \multicolumn{2}{|c|}{ Estadísticos de prueba } \\
\hline & Quejas \\
\hline Chi-cuadrado & $167,043^{\mathrm{a}}$ \\
\hline Grado de libertad & 1 \\
\hline Sig. Asintótica & 0,000 \\
\hline
\end{tabular}

a: 0 casillas $(0,0 \%)$ han esperado frecuencias menores a 5 . La frecuencia mínima de casilla esperada es 165,6.

Fuente: elaboración propia.

Como se visualiza en el cuadro, el valor de «p» es 0,000 menor que $\alpha: 0,05$.

También se puede visualizar que el valor «p<a; por lo que se rechaza $\mathrm{H} 0$, y se acepta la hipótesis alternativa H1. Por ello, se puede concluir en que la cantidad de quejas se redujo con la implementación de la planificación de servicios.

\section{DISCUSIONES}

El escenario pretest del presente artículo son las quejas enviadas por los clientes a través de correos al área de certificaciones, informando que el personal aún no llega a las instalaciones de la planta, almacén o fábrica. El tamaño de muestra del escenario pretest fue de 385 solicitudes de inspección, de las cuales 166 servicios presentaron quejas, conformado por el $43 \%$, mientras que 219 inspecciones no presentaron quejas, representado 
por el 57\%. Además, se implementó la planificación de servicios con el objetivo de reducir las quejas y se solicitó información al área de certificaciones con relación al cliente. Luego, se implementaron formatos con la finalidad de procesar los datos, también se detallaron los pasos para completar correctamente los documentos. Por último, la información fue compartida a todas las áreas involucradas y colaboradores para ejecutar las actividades en campo.

Por otro lado, la información entregada a los inspectores les permitió anticiparse y determinar los materiales a utilizar, también les posibilitó estimar la distancia que existe desde la empresa hasta las plantas, almacenes o empresas de los clientes, donde se van a ejecutar las auditorías, inspecciones o muestreos. Después de implementarse la variable independiente planificación de servicios, se consideró el mismo tamaño de muestra y se obtuvo como resultado que 40 servicios presentaban quejas, representado por el 10\%, mientras que 345 inspecciones no presentan quejas, conformado por el $90 \%$. En otras palabras, que la planificación de servicios generó un impacto positivo en la variable dependiente al reducir el número original de quejas. Por ello, es trascendental planificar las operaciones con el objetivo de organizar, de manera eficiente y eficaz, los recursos de la organización.

\section{CONCLUSIONES}

1. Se observa que el valor de «p» es 0,000 , el cual es menor a 0,05. Por lo tanto, de este resultado se concluye que la planificación de servicios influye positivamente en la cantidad de quejas.

2. Se logró reducir la cantidad de quejas de los clientes mediante correos, expresando que los inspectores aún no llegaban a sus instalaciones, de 43 a 10\%, como resultado de la planificación de servicios.

3. La cantidad de quejas en el pretest fue de 166 y en el postest, 40. Así, la planificación redujo 126 quejas realizadas por los clientes y mejoró el grado de percepción del consumidor hacia la empresa de servicios.

\section{RECOMENDACIONES}

- Se debería estimar la demanda de servicios, con la finalidad de saber cuáles son los meses con mayores ventas y poder reducir la incertidumbre.

- Para estimar la demanda, se puede utilizar el método cualitativo-opinión experta y el modelo matemático de regresión lineal u otro método que se ajuste al tipo de demanda que existe en la empresa considerando siempre los factores de correlación y de determinación.

\section{REFERENCIAS BILIOGRÁFICAS}

[1] Castillo, L. (2013). Diseño de un modelo de gestión por procesos para el Departamento de Química de la Universidad Técnica Particular de Loja. (Tesis de maestría). Universidad Técnica Particular de Loja, Ecuador.

[2] Díaz, E. (2015). Propuesta de un modelo de gestión por procesos en pymes de la industria gráfica en el sector norte de la ciudad de Quito. (Tesis de maestría). Universidad Andina Simón Bolivar, Sucre.

[3] Gallego, T. (2013). Gestión integral. Castellón de la Plana, España: Publicaciones de la Universidad Jaime I. Recuperado de http://repositori.uji.es/ xmlui/bitstream/handle/10234/54803/s48. pdf? sequence $=1 \&$ isAllowed $=\mathrm{y}$.

[4] Hernández, R.; Fernández, C. y Baptista, M. (2014). Metodología de la investigación. México, D. F., México: McGraw-Hill.

[5] Herrera, Y. (2013). Diseño de un sistema de gestión por procesos para un restaurante hornados Dieguito. Recuperado de http:// repositorio.puce.edu.ec/handle/22000/9361.

[6] Imbaquingo, E. (2013). Diseño de un sistema de gestión por procesos para el mejoramiento de la productividad en los procesos de cultivo y post-cosecha de la empresa florícola Floreloy S. A. en la ciudad de Cayambe (Tesis de grado previa a la obtención del título de ingeniero industrial). Universidad Técnica del Norte, Ecuador. Recuperado de http://repositorio.utn. edu.ec/handle/123456789/1065.

[7] Junta de Castilla y León (2004). Guía para la gestión por procesos. Recuperado de https:// bibliotecadigital.jcyl.es/es/catalogo_imagenes/ grupo.cmd?path=10121906.

[8] Mallar, M. (2010). La gestión por procesos: un enfoque de gestión eficiente. Visión de Futuro, 13(1), s. n. Recuperado de http://www.redalyc. org/pdf/3579/357935475004.pdf.

[9] Merino, Y. (2015). Gestión por procesos y su relación con las capacidades de gestión administrativas-sede central de Essalud, en el distrito de Jesús María, Lima 2014. (Tesis de maestría). Universidad César Vallejo, Lima. 
[10] Muñoz, K. y Andrade, J. (2017). Diseño de un modelo de gestión que permita administrar los recursos disponibles en el invernadero inteligente del INIAP localizado en las instalaciones de la ESPE orientado a la producción de semilla de papa certificada. (Tesis de maestría). Universidad Internacional del Ecuador, Quito.

[11] Pérez, J. (2004). Gestión por procesos. Cómo utilizar ISO 9001:2000 para mejorar la gestión de la organización. Madrid, España: Esic.

[12] Pérez, M. (2017). Mejora en la gestión de los talleres externos de confección en una empresa exportadora; enfocado en un nivel de cumplimiento y calidad. (Tesis de maestría). Universidad Nacional Mayor de San Marcos, Lima.
[13] Sánchez, H. y Reyes, C. (2002). Metodología y diseños en la investigación científica. Lima, Perú: Universidad Ricardo Palma.

[14] Suárez, E. (2017). Análisis estructural del modelo EFQM de excelencia: el papel mediador de la gestión por procesos y la planificación estratégica. (Tesis doctoral). Universidad de Sevilla, Sevilla.

[15] Valenzuela, R. (2017). Gestión por procesos y clima social laboral de los trabajadores del Instituto Nacional de Defensa Civil de Lima 2017. (Tesis de maestría). Universidad César Vallejo, Lima. 


\section{Process management model to improve performance in the agri-food sector}

Gabriel Delgado Seclén Willy CALSINA MiRAMIRA ${ }^{2}$

\begin{abstract}
This research proposes improvements for the agri-food sector, which presents problems including: complaints from customers, who state that auditors and inspectors do not arrive at agreed-upon times; lack of procedures, which confuses clients since inspectors complete different operations for the same service; and finally, lack of input and output control of stored materials, so material required by all organizational personnel is frequently missing. After explaining the problems in the agri-food sector, this study aims to mitigate these directly-related problems, given that the client currently has a bad impression about the service. Likewise, the investigation was performed on a company that provides inspection, audit, testing and food certification services. The objective of this study is to determine the impact of a business process management model on the performance of the agri-food sector, with the aim of reducing complaints, standardizing activities carried out by the inspectors in the field and accounting for the materials required by all collaborators. The design of this research is time-series quasi-experimental; descriptive and inferential statistics have also been applied. Finally, the results obtained were: reduction of complaints, standardization of fieldwork and order fulfillment, all of which can be seen in the hypothesis testing.
\end{abstract}

Keywords: Business process management; complaints; procedures; materials.

\section{INTRODUCTION}

This study was conducted on a service company that carries out inspections, audits, testing and food certification requested by public and private entities. This work was carried out in the agrifood sector, given that the company has problems in its different subareas.

In agreement with the procedure manual of the company studied, certification department partners and clients agree to the date, time and place where the inspection, audit or sampling will be conducted. According to the operations department, this is where the first problem occurs: as they have not developed processes that allow operational planning, which leads to improvised decision-making that does not comply with the work agreements and causes general disorganization. Subsequently, the certification department notifies the operations department via e-mail, informing that the service was agreed to with the client and the work schedule. Then, the coordinator appoints the inspector and gives him the paperwork so that he, in turn, can carry out his tasks. According to the certification department, customers send e-mails (complaints) informing that staff is yet to arrive at the plant facility, warehouse or office. These delays may cause users to form a bad impression of the corporation and they may choose to hire other certification companies. This would thereby be reflected in sales, producing a negative impact on organizational profit.

On the other hand, service company departments place orders with the purchasing department, which in many occasions are not delivered by the agreed-upon time. Therefore, to solve these problems, the purchasing department makes emergency purchase orders from suppliers, with a $15 \%$ surcharge, which is directly reflected in costs, and are the result of poor management. The purchasing department also reports that they lack control of the

ndustrial Engineer from the Universidad Señor de Sipán. Currently working as supervisor at Intertek Testing Services Perú S. A., Lima.

E-mail: juan.delgado@intertek.com

2 Industrial Engineer and Master of Senior Management from the Universidad Nacional Mayor de San Marcos.

E-mail: willy.calsina@unmsm.edu.pe 
input and output of stored materials, such as seals, plastic bags, plastic bottles, tape, office supplies, etc., that are used by inspectors, supervisors, auditors and partners in the field and at company facilities. Another deficit identified, according to the purchasing department, is the organization's lack of knowledge about costs when issuing a purchase order, when an order should be placed, and the optimal quantity to be ordered. These factors should be considered because it will lead to better inventory cost management.

Likewise, they lack procedures that serve as a guide for inspectors during fieldwork, which causes activities to not be standardized. Moreover, this may confuse the client, since the inspectors carry out various forms of work, as well as State-run institutions-such as Sanipes [National Service of Fisheries Health] and Digesa [General Directorate of Environmental Health]_, which are responsible for assessing the technical competency of the inspector. These entities could sanction the company and bar them from operating; they could also perform internal audits in order to qualify the level of technical competency of inspectors. It is important that the organization has clear objectives that are understood and shared by all members of the company. Otherwise, the results will not be favorable and will be reflected in the productivity and profitability of the company and above all could result in unsatisfied customers, since goals are not achieved and as a result of improperly-defined objectives. If this situation continues, the organization will continue to incur losses, which could cause customers to cancel services and choose to work with other companies, causing large losses; under this scenario the company would end up bankrupt.

\section{THEORETICAL FRAMEWORK}

For Muñoz and Andrade (2017), the term "management" is a set of stages or steps that are executed to finish a job, define a project or manage a corporation or organization. Likewise, Gallego (2013) points out that there are three process groups. The first one is strategic, which includes those activities related to the definition of the mission, vision, goals of the company and the design of strategies. The second are the operational processes, which are those that are directly related to the productive tasks of the organization and linked to the execution of the product or service. Finally, the last group is responsible for supporting all departments of an organization.
Imbaquingo (2013) defines business process management as the improvement of all tasks, activities and processes, adding value to each activity from the beginning to the end, which in turn impacts consumer satisfaction and expectations. On the other hand, Mallar (2010) defines business process management as a convenient management model for the current time, used by different companies that seek efficiency in operations and constantly improving results. As shown in both definitions, commonalities exist when addressing the addition of value to all processes in order to satisfy the needs and requirements of the client.

Pérez (2004) maintains that planning is to do things properly to achieve pursued objectives. In a similar vein, the Junta de Castilla y León (2004) indicates that planning starts with the evaluation, analysis and design of the different tasks and activities to be performed, in order to design different roles (describing the human resources system, setting and monitoring objectives of the different units, etc.). The implementation of service planning is relevant to avoid any type of complaint and claim. In this regard, the International Organization for Standardization defines the complaint as the expression of dissatisfaction made to an organization, with respect to its products and services, which occurs when the organization fails to meet the needs of the consumer.

In his study, Pérez (2017) improved delivery times, which were a cause of annoyance for customers, and reduced them by $67.06 \%$ to $62.38 \%$ in the first month; this had a positive impact on the level of compliance. For resource planning, the author used the Gantt chart and the research was conducted in a textile company. Although that study and the present work occur in two different sectors, the objective is the same: to plan the use of resources and to use them efficiently. Suárez (2017) associated the activities of the positions and the areas of the organizations through a sequence of work that establishes the form and procedures that seek maximum productivity, achieving in parallel their objectives and consumer satisfaction. The author emphasizes that, for maximum efficiency, the activities must be planned, managed and improved to satisfy internal clients and external clients. Likewise, Valenzuela (2017) conducted a study with the purpose of verifying whether there is a relationship between business process management and the social work environment, by planning resources, defining activities and programming the institution's operational plans. 
The results obtained made it possible to conclude that there is a moderate positive relationship between the variables; even the scenario is similar to that presented in this article, since it is important to know the activities and, above all, to put them into practice in order to standardize the processes and reduce the deviations that may occur before, during and after providing some good or service. Díaz (2015) prioritized the implementation of procedures, flow charts and management indicators in order to better understand the activities and processes, as well as to assess whether the objectives of the organization are met. The author points out that the processes must be known and that is achieved through the procedures and flowcharts. He also mentioned that it is important to measure the processes in order to determine whether or not the purposes are being achieved. If not, other mechanisms must be established to meet the objectives and achieve the goals. That study focuses on SMEs in the graphic design industry, and although the research scenario is different, the author's objective is to document the processes, implement procedures and diagrams that allow to better understand the activities, using the Ecuadorian technical standard to implement the business process management model. In this work the technical standards of the State-run institutions such as Sanipes, Inacal and Digesa were used, according to the activities to which the service company is engaged. In addition, it is relevant to comply with the procedures established by the State-run institutions; otherwise, the company would be sanctioned. Thus, the main objective of the implementation of the procedures was to standardize fieldwork and avoid confusion in clients, because they affirmed that the inspectors conducted the work in different ways, despite rendering the same service.

On the other hand, Merino's research (2015) focused on demonstrating whether there is a relationship between business process management and administrative management capabilities. The result was that there is significant evidence to state that there is a relationship between both variables. Moreover, the purpose of the research is to meet the objectives of EsSalud headquarters, so it seeks to solve its problems by using the business process management model to meet the objectives of this entity through service planning.

On a similar vein, Castillo (2013) points out that the lack of procedures and processes for the recording of financial expenses, purchasing processes and budgets causes delays in administrative activities.
The purpose of the author is to describe the processes and implement procedures with the purpose of standardizing the activities and reducing waiting times when carrying out administrative procedures. This work implemented inspection and sampling procedures for products based on Peruvian technical standards, aiming to standardize fieldwork for the inspectors and to comply with the provisions of the State-run institutions.

In that sense, the study by Herrera (2013), described above, indicates that the purpose was to identify the problems, analyze the processes and act appropriately. Therefore, management indicators were designed to measure compliance with the objectives and record information. The author emphasized that the success of the organization is achieved when the external and internal customers are satisfied, and the company's resources are efficiently used. In addition, he pointed out that business process management made it possible to have advantages over other companies and to continuously improve processes. This article prioritized not only the implementation of the procedure, but also service planning, the main problems of the agri-food sector.

\section{METHODOLOGY}

This research is experimental, as one or more independent variables will be manipulated intentionally (Hernández et al., 2010).

\section{Design}

The type of design used is time series quasi-experimental (Sánchez \& Reyes, 2002).

\section{Population}

All inspection requests.

\section{Sample}

385 inspection requests.

\section{Hypothesis}

Service planning reduces the number of complaints.

\section{Dependent variable}

Number of complaints.

\section{Independent variable}

Service planning. 


\section{Scale of measurement}

Nominal scale.

\section{Descriptive statistic}

The mathematical operation or descriptive statistics that was used was counting.

\section{Inferential analysis}

Chi-square goodness of fit test.

\section{Techniques}

Desk research and observation, fundamental techniques that helped the researcher obtain the data.

\section{Instruments}

The instruments used were Excel files and the checklist, which was delivered by the certification and operations departments.

\section{RESULTS}

Hypothesis:

Hi: Service planning reduces the number of complaints.

Where:

X: Service planning implementation.

Y: Number of complaints.

- Analysis unit: Inspection request.

- Population: All inspection requests from the agri-food sector (infinite).

- Sampling: Pretest of 385 inspection requests and posttest of 385 inspection requests.

Before presenting the results, the following hypotheses were raised:

$$
\begin{aligned}
& \text { H0: } u 1=u 2 \\
& \text { Hi: } u 1 \neq u 2 \\
& \alpha=0,05
\end{aligned}
$$

Where:

u1: Number of complaints for the pretest situation.

u2: Number of complaints for the posttest situation. a: Alpha level, also called error level.

The following table shows the Chi-square goodness of fit test:

Table 1. Complaints.

\begin{tabular}{|c|c|c|c|}
\cline { 2 - 4 } \multicolumn{1}{c|}{} & Observed No. & Expected No. & Residual \\
\hline 0 & 345 & 219.5 & 125.6 \\
\hline 1 & 40 & 165.5 & -125.6 \\
\hline Total & 385 & & \\
\hline
\end{tabular}

Source: Prepared by the authors.

The following table shows the results of the previous test:

Table 2. Results of Chi-square goodness of fit test.

\begin{tabular}{|c|c|}
\hline \multicolumn{2}{|c|}{ Test statistics } \\
\hline & Complaints \\
\hline Chi-square & $167.043^{\mathrm{a}}$ \\
\hline Degree of freedom & 1 \\
\hline Asymptotic significance & 0.000 \\
\hline
\end{tabular}

Source: Prepared by the authors.

a. 0 boxes $(0.0 \%)$ have expected frequencies below 5 . The minimum expected box frequency is 165.6 .

As shown in the table, the p-value is 0.000 , less than $\alpha$ : 0.05 .

It is also shown that the $\mathrm{p}$-value $<\alpha$; therefore, $\mathrm{HO}$ is rejected, and the alternative hypothesis $\mathrm{H} 1$ is accepted. Therefore, it can be concluded that the number of complaints was reduced with the implementation of service planning.

\section{DISCUSSION}

The pretest scenario of this article is the complaints sent by clients via e-mail to the certification department, informing that the personnel has not yet arrived at the plant facility, warehouse or office. The sample size of the pretest scenario was 385 inspection requests, of which 166 services, which represents $43 \%$, filed complaints, while 219 , or $57 \%$, did not. In addition, service planning was implemented in order to reduce complaints and client information was requested from the certification department. Then, formats were implemented to process the data and the steps to correctly complete the documents were detailed. Finally, the information was shared with all the areas and collaborators involved in implementing field activities. 
On the other hand, the information provided to the inspectors allowed them to anticipate and determine the materials to be used. It also allowed them to estimate the distance from the company to the client's plant facilities, warehouses or offices, where the audits, inspections or testing would be conducted. After implementing the independent variable service planning, the same sample size was used and the result was that 40 services, or $10 \%$, presented complaints, and 345 inspections, or $90 \%$, did not. In other words, service planning had a positive impact on the dependent variable by reducing the number of complaints. For this reason, it is crucial to plan operations in order to efficiently and effectively organize organization resources.

\section{CONCLUSIONS}

1. It is observed that the p-value is 0.000 , which is less than 0.05 . Therefore, it is concluded from this result that service planning reduces the number of complaints.

2. The number of customer complaints by e-mail expressing that inspectors had not yet arrived at their facilities were reduced from $43 \%$ to $10 \%$ as a result of service planning.

3. The number of complaints in pretest was 166 and 40 in posttest. Thus, the planning reduced customer complaints by 126 and improved consumer perception towards the service company.

\section{RECOMMENDATIONS}

- Demand for services should be estimated in order to reduce uncertainty and know which months have the highest sales.

- To estimate demand, the qualitative expert opinion method, the linear regression model or any other method that fits the type of demand that exists in the company can be used, always considering correlation and determination factors.

\section{REFERENCES}

[1] Castillo, L. (2013). Diseño de un modelo de gestión por procesos para el Departamento de Química de la Universidad Técnica Particular de Loja. (Tesis de maestría). Universidad Técnica Particular de Loja, Ecuador.

[2] Díaz, E. (2015). Propuesta de un modelo de gestión por procesos en pymes de la industria gráfica en el sector norte de la ciudad de Quito. (Tesis de maestría). Universidad Andina Simón Bolivar, Sucre.
[3] Gallego, T. (2013). Gestión integral. Castellón de la Plana, España: Publicaciones de la Universidad Jaime I. Recuperado de http://repositori.uji.es/ xmlui/bitstream/handle/10234/54803/s48. pdf? sequence $=1 \&$ isAllowed $=y$.

[4] Hernández, R.; Fernández, C. y Baptista, M. (2014). Metodología de la investigación. México, D. F., México: McGraw-Hill.

[5] Herrera, Y. (2013). Diseño de un sistema de gestión por procesos para un restaurante hornados Dieguito. Recuperado de http:// repositorio.puce.edu.ec/handle/22000/9361.

[6] Imbaquingo, E. (2013). Diseño de un sistema de gestión por procesos para el mejoramiento de la productividad en los procesos de cultivo y post-cosecha de la empresa florícola Floreloy S. A. en la ciudad de Cayambe (Tesis de grado previa a la obtención del título de ingeniero industrial). Universidad Técnica del Norte, Ecuador. Recuperado de http://repositorio.utn. edu.ec/handle/123456789/1065.

[7] Junta de Castilla y León (2004). Guía para la gestión por procesos. Recuperado de https:// bibliotecadigital.jcyl.es/es/catalogo_imagenes/ grupo.cmd?path=10121906.

[8] Mallar, M. (2010). La gestión por procesos: un enfoque de gestión eficiente. Visión de Futuro, 13(1), s. n. Recuperado de http://www.redalyc. org/pdf/3579/357935475004.pdf.

[9] Merino, Y. (2015). Gestión por procesos y su relación con las capacidades de gestión administrativas-sede central de Essalud, en el distrito de Jesús María, Lima 2014. (Tesis de maestría). Universidad César Vallejo, Lima.

[10] Muñoz, K. y Andrade, J. (2017). Diseño de un modelo de gestión que permita administrar los recursos disponibles en el invernadero inteligente del INIAP localizado en las instalaciones de la ESPE orientado a la producción de semilla de papa certificada. (Tesis de maestría). Universidad Internacional del Ecuador, Quito.

[11] Pérez, J. (2004). Gestión por procesos. Cómo utilizar ISO 9001:2000 para mejorar la gestión de la organización. Madrid, España: Esic.

[12] Pérez, M. (2017). Mejora en la gestión de los talleres externos de confección en una empresa exportadora; enfocado en un nivel de cumplimiento y calidad. (Tesis de maestría). Universidad Nacional Mayor de San Marcos, Lima. 
[13] Sánchez, H. y Reyes, C. (2002). Metodología y diseños en la investigación científica. Lima, Perú: Universidad Ricardo Palma.

[14] Suárez, E. (2017). Análisis estructural del modelo EFQM de excelencia: el papel mediador de la gestión por procesos y la planificación estratégica. (Tesis doctoral). Universidad de Sevilla, Sevilla.
[15] Valenzuela, R. (2017). Gestión por procesos y clima social laboral de los trabajadores del Instituto Nacional de Defensa Civil de Lima 2017. (Tesis de maestría). Universidad César Vallejo, Lima. 